\title{
WYWŁASZCZENIE Z MOCY PRAWA (EX LEGE) \\ A NACJONALIZACJA \\ - REFLEKSJE W PRZEDMIOCIE \\ PUBLICZNOPRAWNYCH INGERENCJI W PRAWO WŁASNOŚCI
}

\section{WPROWADZENIE}

Nacjonalizacja podobnie jak wywłaszczenie jest postacią przekształceń własnościowych i łączy je wiele cech wspólnych ${ }^{1}$. Ich celem jest wywołanie odpowiedniej zmiany podmiotu prawa własności, a podstawa prawna takich działań sa przepisy zawarte w aktach rangi ustawowej. Przesłanką takiego przekształcenia jest interes publiczny wskazany w sposób wyraźny lub dorozumiany. Instytucją, która często towarzyszy refleksji o powyższych, jest konfiskata, znana przede wszystkim prawu karnemu, a więc również prawu publicznemu, jako kara dodatkowa ${ }^{2}$. W polskim prawie karnym oznaczała ona nabycie przez Skarb Państwa mienia lub przedmiotów na podstawie orzeczenia sądowego wydanego w postępowaniu karnym i na podstawie prawa karnego ${ }^{3}$.

Zasadniczo najczęściej przyjmuje się, że nacjonalizacja następuje na podstawie ustawy i bez odszkodowania, natomiast wywłaszczenie w drodze aktu administracyjnego, w którym w modelowym przypadku orzeka się także o stosownej rekompensacie. Jednakże podział ten, skądinąd klarowny i tym samym prosty $\mathrm{w}$ zastosowaniu, nie zawsze znajduje potwierdzenie w realiach prawodawczych. W Polsce po transformacji ustrojowej powyższa dystynkcja wydawała się w wystarczająca do momentu uchwalenia ustawy z 13 października 1998 r. - Przepisy wprowadzające ustawy reformujące administrację publiczna ${ }^{4}$. Mianowicie w art. 73 ust. 1 został wprowadzony skutek w postaci przejęcia z mocy prawa gruntów na rzecz Skarbu Państwa lub właściwej jednostki samorządu terytorialnego, a w ust. 4 określono zasady realizacji obowiązku odszkodowawczego, która to ingerencja publicznoprawna została przez TK nazwana wywłaszczeniem ex lege. Z identycznego mechanizmu skorzystano jeszcze kilkukrotnie, stąd zasadna jest refleksja w zakresie charak-

\footnotetext{
1 Powałowski (2009): 30.

2 Baran (2009): rodz. 4, pkt 3.5.1.

3 Wyrok TK z 25 lutego 1992 r., K 3/91, Lex nr 25275.

${ }_{4}^{4}$ Dz. U. 1998, Nr 133, poz. 872 ze zm. (dalej jako: u.w.r.1998).
} 
teru prawnego takiej ingerencji w prawo własności, w tym wskazanie, czy tego typu normy nie są właściwe nacjonalizacji.

W opracowaniu celowo została pominięta problematyka tzw. specustaw, przede wszystkim z tego względu, że w ich przypadku do odjęcia prawa dochodzi w drodze aktu administracyjnego, tzw. decyzji zintegrowanej. Niemniej $\mathrm{z}$ racji pewnych podobieństw w kwestiach odszkodowawczych (następcze ustalanie i wypłata odszkodowania) zasygnalizować należy, że także i w tym przypadku ustawodawca dokonuje odstępstw od klasycznego wzorca.

\section{NACJONALIZACJA W UJĘCIU DOKTRYNY I W PRAWIE POZYTYWNYM}

Definiowanie nacjonalizacji nie jest sprawą prostą i oczywista. Sam termin ściśle związany jest z łacińskim odpowiednikiem - natio („naród”). W encyklopedycznym ujęciu jest to jedna z form upaństwowienia, przejęcia przez państwo praw własności ziem, przedsiębiorstw i kapitału na podstawie odrębnego aktu prawnego ${ }^{5}$, czy też „likwidacja prywatnej własności, środków produkcji i przejęcia ich na własność społeczną przez państwo"6. Jako jej cechy charakterystyczne wskazuje się, że następuje w drodze aktu prawnego, którego krag adresatów określony jest generalnie. W doktrynie najczęściej podnosi się, że „termin ten oznacza przejęcie przez państwo określonych segmentów gospodarki”7. Na podobne rozumienie wskazuje Michał Bors, który przez nacjonalizację rozumie akt polityczny państwa skierowany przeciwko konkretnemu sektorowi gospodarki $^{8}$ (np. nacjonalizacja sektora naftowego w Iranie ${ }^{9}$ ). Przy tym w zakresie skutków prawnych, jakie nacjonalizacja wywołuje, zgodnie podnosi się, że jest jednym ze sposobów nabycia praw podmiotowych ${ }^{10}$ - jest nabyciem pierwotnym, ale translatywnym ${ }^{11}$. Jak słusznie zauważył Józef Kremis, nacjonalizacja nie miała jednego utartego wzorca, co dotyczyło nie tylko Polski, ale także pozostałych państw socjalistycznych, stąd określenie przedmiotu podlegającego upaństwowieniu każdorazowo wymaga interpretacji konkretnych aktów prawnych ${ }^{12}$.

Natomiast w nauce prawa międzynarodowego termin nacjonalizacja jest definiowany niejednolicie i niekiedy postrzegany jest przez pryzmat wy-

${ }^{5}$ Luszniewicz, Landau (b.d.).

${ }^{6}$ Szymczak (1988): 243.

7 Zob. Żółtowski (2013): 4.

8 Bors (2014): 201.

${ }^{9}$ Zob. Philips Petroleum Co. przeciwko Iranowi, orzeczenie z 29 czerwca 1989 r., < https:// www.trans-lex.org/232300/_iran-us-claims-tribunal-phillips-petroleum-co-iran-v-iran-et-al-21-iran-us-ctr-at-79-et-seq/ > [dostęp: 12.06.2018].

10 Zob. Grzybowski (1974): 239.

11 Grzybowski (1974): 238-239; tak samo Osajda (2009): 5; zob. także Bieniek, Rudnicki (2013): 271.

12 Kremis (2008): 592 
właszczenia. Przykładowo Samy Friedman ujmował nacjonalizację jako szczególną formę wywłaszczenia ${ }^{13}$, Nicholas R. Doman zaś jako wywłaszczenie za odszkodowaniem, natomiast gdy rekompensata nie była przewidziana - jako konfiskatę ${ }^{14}$. Niekiedy pojawiało się stwierdzenie, że jest to wywłaszczenie o charakterze ogólnym i bezosobowym (expropriation of a general and impersonal character $)^{15}$. Pojawiały się także próby jej definiowania, przykładowo uznano, że: „stanowi przeniesienie przez państwo pewnej kategorii dóbr i praw prywatnych w celu ich eksploatacji, kontroli lub zmiany ich dotychczasowego przeznaczenia w interesie państwa" ${ }^{16}$. W krajowej doktrynie wskazuje się, że: „prawo międzynarodowe publiczne nie kwestionuje możliwości przeprowadzenia nacjonalizacji, ponieważ z zasady suwerenności wynika możliwość regulowania przez suwerena stosunków prawnorzeczowych na terytorium poddanym jego władzy (jurysdykcji); ochrona prawnomiędzynarodowa sprowadza się natomiast do wymagania zadośćuczynienia roszczeniom"17.

W literaturze przedmiotu najczęściej wskazuje się, że nacjonalizacja w Polsce ma obecnie walor historyczny, natomiast duże znaczenie miała $\mathrm{w}$ okresie powojennym, przy tym w dużej części była narzędziem politycznym ${ }^{18}$. Jest najczęściej kojarzona przez pryzmat przekształceń własnościowych, jakie dokonały się w latach czterdziestych i pięćdziesiątych XX w. ${ }^{19}$ Według Andrzeja Powałowskiego w ramach tych przekształceń w Polsce nacjonalizacja sprowadzająca się do przejmowania przez państwo od osób prywatnych prawa własności doprowadziła do stanu, w którym sektor państwowy obją ponad 70\% całości gospodarki narodowej ${ }^{20}$. Obejmowała swym zakresem szereg składników majątkowych, w tym przedsiębiorstwa ${ }^{21}$. Przykładowo przedmiotem nacjonalizacji w 1946 r. uczyniono przedsiębiorstwo w znaczeniu przedmiotowo-funkcjonalnym - dotyczyła bowiem zorganizowanego kompleksu majątkowego służącego do prowadzenia określonej działalności gospodarczej ${ }^{22}$. Stąd przejęciu

13 Podobnie Banaszkiewicz (2001): 48.

14 Pessel (2003): 24.

15 Report of the Commission to the General Assembly. Document A15509: Report of the International Law Commission covering the work of its fifteenth session, 6 May-12 July 1963, with annexes. Yearbook of the International Law Commission 1963, vol. 2, New York 1964: 239, pkt 14, < http://legal.un.org/ilc/pulications/yearbooks/english/ilc_1963_v2.pdf.> [dostęp: 12.06.2018].

16 Pradelle (1959): 214.

17 Rudnicki (2007): rozdz. 4.4.1.

18 Baran (2018): rozdz. IV.3.5.1.

19 Do aktów nacjonalizacyjnych w Polsce po II wojnie światowej zalicza się m.in.: przepisy ustawy z 3 stycznia 1946 r. o przejęciu na własność Państwa podstawowych gałęzi gospodarki narodowej (Dz. U. Nr 3, poz. 17); ustawy z 18 listopada1948 r. o przejściu na własność Państwa niektórych lasów i innych gruntów samorządowych (Dz. U. Nr 57, poz. 456); dekretu Polskiego Komitetu Wyzwolenia Narodowego z 6 września1944 r. o przeprowadzeniu reformy rolnej (Dz. U. 1945, Nr 3, poz. 13 ze zm.). Do aktów o faktycznym skutku nacjonalizacyjnym - niezależnie od celu zakładanego przez ustawodawcę - należy również zaliczyć dekret z 26 października1945 r. o własności i użytkowaniu gruntów na obszarze m. st. Warszawy (Dz. U. Nr 50, poz. 279 ze zm.).

20 Powałowski (2011): 585.

${ }^{21}$ Zob. art. 3 ustawy z 3 stycznia 1946 r. o przejęciu na własność państwa podstawowych gałęzi gospodarki; zob. także Kremis (2008): 591.

22 Jak zauważa Bieniek, na podstawie art. 2 ust. 1 lit. a-d ustawy z 3 stycznia 1946 r. o przejęciu na własność Państwa podstawowych gałęzi gospodarki narodowej w związku z przepisami 
podlegały takie składniki majątku przedsiębiorstwa, jak: prawo własności, inne prawa rzeczowe czy obligacyjne, a także własność przemysłowa; zatem zarówno majątek ruchomy, jak i nieruchomości oraz wszelkie prawa. Dla złagodzenie skutków tego aktu prawnego w praktyce wykładnia stara nadawać się tymże normom charakter ekspropriacyjny ${ }^{23}$. Taka nacjonalizacja została dokonana ex lege, a więc wprost z mocy ustawy, niemniej w przypadku nieruchomości niezbędne było wydanie deklaratoryjnej decyzji potwierdzajacej ten fakt i stanowiącej podstawę wpisu nowego właściciela do księgi wieczystej. Co więcej, do elementów składowych nacjonalizacji zalicza się niekiedy także ustalenie odszkodowania ${ }^{24}$, choć kwestia ta nie jest jednoznaczna, w szczególności nie ma pewności, czy ustalone odszkodowanie ma być adekwatne i ekwiwalentne, czy tė̇ może być niepełne, czy też wręcz pozorne. Nacjonalizacja może też przybrać postać nacjonalizacji kapitałowej ${ }^{25}$.

Jak zauważa Ewa Stefańska, przejście prawa własności na podstawie aktów nacjonalizacyjnych następowało najczęściej ex lege, bez konieczności wydawania decyzji administracyjnych ${ }^{26}$. Mogło się zdarzyć i tak, że skutek prawnorzeczowy publicznoprawnej ingerencji następował przez dokonanie zgłoszeń ${ }^{27}$. Natomiast wpisanie do księgi wieczystej nowego właściciela następowało często nie na podstawie decyzji deklaratoryjnej ${ }^{28}$, ale na podstawie wydawanego przez organ administracji zaświadczenia ${ }^{29}$. Z kolei dekret z 26 października 1945 r. o własności i użytkowaniu gruntów na obszarze m. st. Warszawy ${ }^{30}$ przewidywał przejście prawa własności gruntów ex lege z dniem jego wejścia w życie (art. 1), a przejście posiadania nieruchomości na rzecz gminy m. st. Warszawy przez dokonanie ogłoszeń ${ }^{31}$. Jednakże cechą wyróżniającą nacjonalizację było to, że przejście prawa własności następowało z woli ustawodawcy w sposób generalny, a nie w drodze aktu administracyjnego, co w świetle klasycznej koncepcji wywłaszczenia jest zasadą ${ }^{32}$. Podkreśla ona, że celem aktów

rozporządzenia wykonawczego Ministra Sprawiedliwości z 11 kwietnia 1946 r. o określeniu osób, których przedsiębiorstwa przechodzą na własność Państwa (Dz. U. Nr 17, poz. 115), przeszły na własność państwa bez odszkodowania przedsiębiorstwa: przemysłowe, górnicze, komunikacyjne, bankowe, ubezpieczeniowe oraz handlowe: Rzeszy Niemieckiej i byłego Wolnego Miasta Gdańska, obywateli Rzeszy Niemieckiej i byłego Wolnego Miasta Gdańska z wyjątkiem osób narodowości polskiej lub innej przez Niemców prześladowanej, niemieckich i gdańskich osób prawnych z wyłączeniem osób prawnych prawa publicznego, spółek kontrolowanych przez obywateli niemieckich lub gdańskich albo przez administrację niemiecką lub gdańską - Bieniek, Rudnicki (2013): 271.

${ }^{23}$ Kremis (2008): 591.

24 Zob. Trzaskowski (2003): 9-56.

25 Powałowski (2011): 31.

26 Stefańska (2009): 365.

27 Zob. Kozłowska, Mzyk (1997): 9-10.

28 Zob. wyrok NSA z 19 marca 1998 r., IV SA 1045/97, Lex nr 45950, oraz uchwałę SN z 27 września 1991 r., III CZP 90/91, OSNC 1992, nr 5, poz. 72.

29 Tak było np. w odniesieniu do dekretu o przeprowadzeniu reformy rolnej. Zob. wyrok SN z 25 marca 1999 r., III RN 165/98, OSNP 2000, nr 3, poz. 90.

30 Dz. U. Nr 50, poz. 279 ze zm.

31 § 1-3 rozporządzenia Ministra Odbudowy z 27 stycznia 1948 r. wydanego w porozumieniu z Ministrem Administracji Publicznej w sprawie obejmowania w posiadanie gruntów przez gminę m. st. Warszawy (Dz. U. 1948, Nr 6, poz. 43); zob. także Kozłowska, Mzyk (1997): 9-10.

32 Zob. Pawłowski (2018b): 226. 
nacjonalizacyjnych było raczej realizowanie określonej polityki władz państwa, a nie działania na rzecz interesu publicznego. W związku z powyższym Stefańska dochodzi do wniosku, że nacjonalizacja jest sprzeczna z zasadami demokratycznego państwa prawnego ${ }^{33}$. To implikuje, że obecnie w Polsce jest niedopuszczalna.

Podobnie postrzega ją Radosław Skwarło, który jako formę prawną jej dokonania wskazuje ustawę, natomiast ewentualne rozstrzygnięcia organów administracji mają znaczenie deklaratoryjne ${ }^{34}$. Stąd jej istota wedle niego zasadza się na przejściu określonej kategorii dóbr na własność państwa właśnie w drodze aktu ustawowego. Nadto jako odmianę nacjonalizacji wymienia komunalizację, którą wyróżnia przejścia prawa własności na rzecz jednostki samorządu terytorialnego ${ }^{35}$.

Jak zauważył jednak TK w orzeczeniu z 25 lutego 1992 r. (K 3/91), nie każdy akt nacjonalizacyjny należy ocenić krytycznie. W szczególności, jego zdaniem, na taką ocenę nie zasługuje dekret z 8 marca 1946 r. o majątkach opuszczonych i poniemieckich ${ }^{36}$. W uzasadnieniu TK podniósł, że u podstaw tych przepisów legły motywy zadośćuczynienia i rekompensaty (art. 2 ust. 1) oraz potrzeba uregulowania sytuacji mienia, które na skutek wypadków wojennych stało się bezpańskie (powyższe implikuje, że wywłaszczenie z mocy ustawy można uznać za dopuszczalne tylko w sytuacjach nadzwyczajnych). Nadto uzasadnieniem, podobnie jak w dekrecie z 8 marca 1946 r., moga być takie wartości, jak zrekompensowanie szkód, jakie poniosło państwo polskie i społeczeństwo, a także ustalenie sytuacji prawnej mienia, którego podmiot przestał istnieć.

Z kolei w stosunku do przejęcia z mocy ustawy majątku PZPR w 1990 r. nie mówi się o nacjonalizacji, czy wywłaszczeniu, gdyż podmiot ten w momencie uchwalenia ustawy już nie istniał. Stąd w tym przypadku, jak orzekł TK, doszło raczej do przepadku mienia (które stało się bezpodmiotowe), co - jak stwierdzono w opinii biegłego - można było traktować jako „rodzaj sankcji cywilnej za sposób nabycia tego majątku przez PZPR w czasie, kiedy uważała siebie za "przewodnią siłę polityczną społeczeństwa«" (TK K 3/91).

Natomiast w obecnym stanie prawnym w Polsce nacjonalizacja w znaczeniu przejęcia na własność państwa generalnie określonych przedmiotów własności prywatnej (lasów, majątków ziemskich, kopalń) nie mieści się w porządku konstytucyjnym. Przymusowe przejęcie konkretnego majątku może nastapić w drodze wywłaszczenia. Stąd - jak zauważył Konrad Osajda, akty nacjonalizacyjne sa de lege lata fundamentali niedopuszczalne i tym samym dokonanie takiego przejęcia praw wymaga zmiany Konstytucji $\mathrm{RP}^{37}$. Niemniej chociaż w Polsce nie dokonuje się nacjonalizacji - zdaniem niektórych chociażby z uwagi na zakaz wynikajacy implicite z art. 21 ust. 2 Konstytucji RP - to jednak bywa ona prak-

\footnotetext{
33 Stefańska (2009): 366.

34 Tak samo Pilich (2017): 990.

35 Skwarło (2006): 75.

${ }^{36}$ Dz. U. Nr 13, poz. 87.

37 Osajda (2009): 25.
} 
tykowana w innych państwach. Co więcej, również w naszym kraju utrzymuja się konsekwencje prawne nacjonalizacji, których rozważanie współcześnie jest konieczne, m.in. w sprawach reprywatyzacyjnych (rewindykacja mienia znacjonalizowanego lub uzyskanie odszkodowania) ${ }^{38}$.

Także Leszek Garlicki uważa, że poza konstytucyjnym pojęciem „wywłaszczenia" pozostaje nacjonalizacja, rozumiana jako przymusowe odjęcie własności na dużą skalę, obejmujące całe dziedziny gospodarki, a przy tym zastanawia się, czy w świetle art. 20 Konstytucji RP, a więc na tle gwarancji dla własności prywatnej, byłaby w ogóle dopuszczalna ${ }^{39}$.

\section{WYWŁASZCZENIE Z MOCY PRAWA (EX LEGE) PO TRANSFORMACJI USTROJOWEJ}

Wywłaszczenie z mocy prawa stało się przedmiotem szerszego dyskursu w Polsce po 1989 r. w związku z art. 73 u.w.r.1998. Na podstawie ust. 1 tego przepisu nieruchomości zajęte pod drogi publiczne, a będące we władaniu Skarbu Państwa lub jednostek samorządu terytorialnego, niestanowiace ich własności stały się z mocy prawa z dniem 1 stycznia 1999 r. ich własnością za odszkodowaniem. Wyjątkowość zastosowanej metody uwłaszczenia na wielka skalę wzbudziła w praktyce ogromne kontrowersje, czego wyrazem jest między innymi czterokrotne wypowiedzenie się w tej sprawie przez TK (P 5/99, SK 11/02, K 43/07, K 20/09), który generalnie uznał przyjęte rozwiązania za konstytucyjne $^{40}$. Jednym $\mathrm{z}$ ważniejszych argumentów było uznanie, że regulacja ta dotyczyła $\mathrm{w}$ istocie nieruchomości już faktycznie wywłaszczonych (P 5/99). Największe wątpliwości wzbudził ust. 4 tego artykułu, który - po pierwsze - odroczył możliwość składania wniosków o odszkodowanie o dwa lata oraz, po drugie, ograniczył możliwość ich składania do końca 2005 r. dopuszczał zatem możliwość przedawnienia się tego roszczenia, co $\mathrm{w}$ przypadku klasycznej koncepcji wywłaszczenia jest niemożliwe (tym bardziej jeśli uwzględni się możliwość jego uprzedniego ustalenia i wypłaty). W orzeczeniu z 2000 r. TK wprost stwierdził, że uznania za konstytucyjny przepisu z art. 73 ust. 1 u.w.r. $1998 \mathrm{w}$ żadnej mierze nie należy traktować jako akceptacji analogicznych zabiegów faktycznych i prawodawczych w przyszłości. Stosowanie tak szczególnych instrumentów prawnych, na tak wielką skalę dopuszcza także ETPC, dla którego przesądzającym argumentem jest potrzeba uporządkowania stosunków społecznych wynikających z zaszłości historycznych i związanych z transformacją ustrojowa ${ }^{41}$.

38 Pilich (2017): 990.

39 Garlicki (2016): pkt 16.

40 Zob. Pawłowski (2018b): 316-321.

${ }^{41}$ Zob. np. wyrok ETPC z 22 stycznia 2004 r. w sprawie Jahn $i$ inni $v$. Niemcy, skarga nr 46720/99 (także skargi: nr 72203/01 i 72552/01), Lex nr 100358; wyrok ETPC z 8 grudnia 2011 r. w sprawie Althof $i$ inni v. Niemcy, skarga nr 5631/05, Lex nr 1054586. 
Mimo podkreślania wyjątkowości i konieczności skorzystania z takiej procedury, a więc akcentując jej jednorazowość, ustawodawca jeszcze dwukrotnie wprowadzał podobne przepisy o charakterze porządkującym. Moca art. 37a ust. 1 ustawy z 8 września 2000 r. o komercjalizacji, restrukturyzacji i prywatyzacji przedsiębiorstwa państwowego „Polskie Koleje Państwowe” (dodanego w 2003 r. $)^{42}$ przejęto na własność Skarbu Państwa grunty wchodzące w skład linii kolejowych pozostajace w dniu 28 lutego 2003 r. we władaniu PKP SA, niestanowiące własności Skarbu Państwa, jednostek samorządu terytorialnego lub PKP SA. Nastapiło to za odszkodowaniem określanym analogicznie do art. 73 ust. 4 u.w.r.1998. Ustawą tą wprost naruszono zastrzeżenie wyrażone przez TK w 2000 r., że mechanizm zastosowany w art. 73 ustawy z 1998 r. nie może być traktowany jako przyzwolenie na analogiczne zabiegi faktyczne i prawodawcze w przyszłości. Co więcej, to właśnie wyrok TK z 2000 r. (P 5/99) został wprost wskazany jako podstawa przesądzenia o dopuszczalności, a tym samym konstytucyjności takiego rozwiązania.

Po raz ostatni z podobnego rozwiązania skorzystano z $2011 \mathrm{r}$. na podstawie art. 8 ustawy z 18 sierpnia 2011 r. o zmianie ustawy o ochronie przyrody oraz niektórych innych ustaw ${ }^{43}$, powielając rozwiązania przyjęte $\mathrm{w}$ poprzednich dwóch ustawach - objęto nim grunty o nieuregulowanym stanie prawnym, co samo w sobie stanowi wyraz nadmiernego pragmatyzmu, gdyż w ogólnej ustawie wywłaszczeniowej istnieją przepisy pozwalające na ich przymusowe przejęcie bez potrzeby stosowania ekstraordynaryjnych metod.

Wskazany powyżej sposób wywłaszczenia nie zapewnia tak silnej ochrony, jak skorzystanie z reguł obowiązujących w klasycznej koncepcji, m.in. z racji braku zapewnienia prawa do sądu, a więc kontroli aktu wywłaszczeniowego przez sądownictwo administracyjne, czy naruszenia zasady równości wobec praw. Zagrożenie to dostrzega m.in. Tadeusz Woś, a także Czeski Sąd Konstytucyjny ${ }^{44}$. Podobnie jak w Czechach, przeprowadzenie wywłaszczenia w drodze ustawy jest również niedozwolone na Słowacji, gdzie w Konstytucji wprost stwierdza się, że wywłaszczenie można przeprowadzić wyłącznie na podstawie ustawy, co uniemożliwia jej dokonanie za pomoca ustawy (art. 20 ust. 4$)^{45}$. W świetle powyższego Libor Cibulka podnosi, że wywłaszczenie za pomoca ustawy jest nacjonalizacja, a ta $\mathrm{w}$ demokratycznym państwie słowackim jest niedopuszczalna ${ }^{46}$, która to reguła była wyrażona także przez Słowacki Sąd Konstytucyjny ${ }^{47}$.

Powyższe regulacje, przede wszystkim art. 73 u.w.r.1998, znalazły w doktrynie również inną interpretację. Przykładowo Radosław Skwarło jednoznacznie stwierdził, że artykuł ten jest przepisem o charakterze nacjonalizacyjnym

${ }^{42}$ Dz. U. Nr 80, poz. 720.

${ }^{43}$ Dz. U. Nr 224, poz. 1337.

${ }_{44}$ Wyrok CSK z 17 marca 2009 r., PL. ÚS 24/08, nr. 124/2009 Sb (N 56/52 SbNU 555), <http:// www.usoud.cz/en/decisions> [dostęp: 12.06.2018].

45 Zob. także Chmielewski (2010): 57.

46 Cibulka (2006): 149.

47 Orzeczenie Sądu Konstytucyjnego Republiki Słowackiej z 3 kwietnia 1996 r., PL. ÚS 38/95. 
i komunalizacyjnym jednocześnie ${ }^{48}$. Także Osajda jest zwolennikiem stanowiska, że z dniem 1 stycznia 1999 r. przeprowadzono nacjonalizację gruntów zajętych pod drogi publiczne ${ }^{49}$. Mimo jednak generalnej krytyki tego trybu odjęcia praw, TK tuż po zmianach ustrojowych stwierdził, że konstrukcja przejścia ex lege określonego mienia (w tym i posiadania) na rzecz Skarbu Państwa, która posłużyła się ustawa z 9 listopada 1990 r. o przejęciu majątku byłej Polskiej Zjednoczonej Partii Robotniczej w art. 1 ust. 1 i 2 sama w sobie nie jest obca polskiemu prawu, a tym samym nie jest niekonstytucyjna (TK K3/91).

Współcześnie jeden z nielicznych przykładów konstytucyjnego wywłaszczenia ex lege stanowi art. 223 ust. 1 ustawy z 20 lipca 2017 r. - Prawo wodne ${ }^{50}$, normujący kwestie związane $\mathrm{z}$ trwałym zajęciem, w sposób naturalny przez śródlądowe wody płynące lub wody morza terytorialnego albo morskie wody wewnętrzne gruntów prywatnych. Skoro właścicielem takich wód jest co do zasady Skarb Państwa (nacjonalizacja wód nastapiła ustawą z 1962 r.), to zasadne jest, by z momentem dokonania się takiego zdarzenia z mocy prawa nastapiła zmiany podmiotu prawa własności ${ }^{51}$.

\section{WYWLASZCZENIE Z MOCY USTAWY A NACJONALIZACJA}

Jak zauważył Stefan Grzybowski, „cała konstrukcja wywłaszczenia oraz nacjonalizacji oparta jest na założeniu istnienia praw, które ulegaja wywłaszczeniu lub znacjonalizowaniu oraz przechodzą na inne podmioty" ${ }^{2}$. Wśród cech wspólnych obu rodzajów przymusowego pozbawienia mienia na rzecz państwa w doktrynie podnosi się, że warunkiem ich przeprowadzenia jest istnienie pewnego celu publicznego oraz wypłata odszkodowania za przejęty w ten sposób majątek ${ }^{53}$. Niemniej nacjonalizacja może także odbyć się bez odszkodowania bądź za odszkodowaniem częściowym, a nawet pełnym $^{54}$, jednakże w tym pierwszym przypadku stanowi wyraźną różnicę w postrzeganiu obu instytucji55. Tymczasem wywłaszczenie we współczesnym państwie prawnym co do zasady jest przeprowadzane za odszkodowaniem, które w konstytucjach określa się jako: odpowiednie, godziwe, słuszne bądź sprawiedliwe - ma być adekwatne i ekwiwalentne, a więc umożliwić odtworzenie wywłaszczonego prawa w miejscowych warunkach. Mimo toczacych się sporów co do jego wysokości, panuje jednak zgodność, że brak ustalenia i wypłaty odszkodowania nie pozwala zakwalifikować danej ingerencji publicznoprawnej jako ekspropriacji.

${ }^{48}$ Skwarło (2006): 75.

${ }^{49}$ Osajda (2009): 6 i podana tam literatura.

${ }^{50}$ Dz. U. 2017, poz. 1566 (dalej jako: u.p.w.).

${ }^{51}$ Zob. także art. 17 ust. 1 ustawy z 18 lipca 2001 r. - Prawo wodne (t.jedn.: Dz. U. 2017, poz. 1121) oraz Pawłowski (2018b): 333-338.

${ }^{52}$ Grzybowski (1974): 239.

53 Żółtowski (2013): 4.

${ }^{54}$ Zob. Dudek (1976): 20-21.

${ }^{55}$ Zob. przyp. 5. 
To, co wyróżnia nacjonalizację, to fakt, że za jej pomocą przejmuje się istniejące grunty, najczęściej nieruchomości, niekiedy przedsiębiorstwa. Nadto można również nią objąć rzeczy ruchome, których z kolei nie da się wywłaszczyć, gdyż co do zasady można je zastapić innymi, takimi samymi, stąd nie zachodzi przesłanka niezbędności. Nacjonalizacja nie jest zatem ukierunkowana na przyszłość, nie służy realizacji nowych celów publicznych, ale wykorzystuje istniejące mienie do celów państwa, niekiedy wręcz celów politycznych. Odwrotnie jest natomiast przy ekspropriacji, jej istota sprowadza się do realizacji nowych celów, w szczególności wznoszenia różnorodnych obiektów budowlanych. Cel ten musi być dostatecznie sprecyzowany i możliwy do osiagnięcia, gdyż w przeciwnym razie może zaktualizować się obowiązek restytucyjny. I właśnie możliwość żądania zwrotu wywłaszczonego prawa, przede wszystkim własności nieruchomości, stanowi cechę właściwą tylko ekspropriacji i akcentuje konieczność realizacji inwestycji w określonych ustawowo ramach czasowych - cel musi być realny, gdyż w przeciwnym razie pozyskiwanie prywatnych nieruchomości pozostawałoby poza jakąkolwiek kontrolą. A taka arbitralność działania administracji publicznej jest współcześnie generalnie negowana i niezgodna z zasadami demokratycznego państwa prawnego. Natomiast w stosunku do wywoływania skutku przewłaszczeniowego w drodze ustawy instytucja ta nie ma zastosowania, gdyż pożądany cel, przykładowo obiekty budowlany, już istnieje, nie ma zatem elementu potrzeby jego realizacji - cel ten jest natychmiastowo osiagnięty, gdyż został już zrealizowany w przeszłości, najczęściej przez podmiot prawa prywatnego, a aktem nacjonalizacyjnym został jedynie upaństwowiony. Nie ma zatem ryzyka braku jego nieosiagnięcia, stąd gwarancje w postaci obowiązku zwrotowego są zbędne. Nacjonalizacja ma zatem w tym znaczeniu charakter deklaratoryjny w zakresie celów i potrzeb państwa, że potwierdza, iż niektóre części mienia prywatnego przechodzą na jego rzecz. Natomiast wywłaszczenie jest konstytutywne - wskazuje cel publiczny i jednocześnie nakazuje jego osiagnnięcie w nieodległej przyszłości.

Najczęściej podnoszonym argumentem przy rozróżnianiu obu rodzajów ingerencji jest mechanizm nabycia prawa przez państwo. W klasycznej koncepcji wywłaszczenia modelową formą prawną pozyskania niezbędnych praw jest akt administracyjny, a więc norma indywidualna i konkretna ${ }^{56}$. Co więcej, tezy, że wywłaszczenie może nastapić w drodze ustawy, stawiane były raczej wyjątkowo ${ }^{57}$. Jednoznaczne stanowisko w tej kwestii zajmuje Słowacki Sąd Konstytucyjny, który stwierdza, że wywłaszczenie można przeprowadzić wyłącznie na podstawie ustawy ${ }^{58}$, co jest jednak związane z tym, że w Konstytucji Słowacji w art. 20 ust. 4 implicite przesądza się, że wywłaszczenie jest dopuszczalne wyłącznie na podstawie ustawy, a nie w drodze ustawy, którego to zastrzeżenia Konstytucja RP nie przewiduje - wywodzi się z tego, że po-

${ }^{56}$ Pilich (2017): 991; zob. także zob. Osajda (2019): 3-7; Ignatowicz, Stefaniuk (2012): 115117; tak samo Stefańska (2009): 365.

57 W tej kwestii zob. rozważania Zimmermanna (1939): 7.

58 Zob. Zbiór orzeczeń Sądu Konstytucyjnego SR, Koszyce 2001: 21. 
sługuje się tym terminem w znaczeniu materialnym ${ }^{59}$. W świetle powyższego przymusowe pozbawienie praw za pomoca ustawy jest nacjonalizacją. Tym co wyraźnie zbliża nacjonalizację do wywłaszczenia ex lege jest konieczność wydania decyzji deklaratoryjnej adresowanej do dotychczasowego właściciela, potwierdzającej fakt przejścia określonego prawa na rzecz państwa, stanowiącej podstawę do dokonania wpisu w księdze wieczystej, czy innym odpowiednim rejestrze publicznym ${ }^{60}$. Jak wskazuje praktyka, realizacja tego obowiązku często następuje z wieloletnią zwłokąc

Nadto nacjonalizacja nie jest też wprost zauważona w Konstytucji RP, odmiennie niż wywłaszczenie, niemniej zakaz jej dokonywania podyktowany jest przede wszystkim aksjologia, na jakiej zasadzają się współczesne państwa prawa oparte na poszanowaniu praw człowieka. Stąd nacjonalizacja właściwa jest ustrojom totalitarnym czy autorytarnym, które nie liczą się z wolnościami ani prawami jednostek. W konsekwencji nie powinna być stosowana w ustrojach demokratycznych, w szczególności w państwach opartych na prawie naturalnym, w którym ich źródłem (wolności i praw) jest godność jednostki. W sposób niepotrzebny a zarazem nieuzasadniony uderzałaby $\mathrm{w}$ zaufanie do takiego państwa, jako działanie nieproporcjonalne. Takie rozumienie jest właściwe od momentu zakończenia II wojny światowej w związku z ukonstytuowaniem się praw człowieka jako praw podmiotowych, do których, mimo początkowych wątpliwości, należy także prawo własności - bez tego prawa trudno bowiem mówić o ochronie godności jednostki.

W świetle powyższego takie zasady, jak: zasada demokratycznego państwa prawnego, równości wobec prawa, zaufania obywateli do państwa i stanowionego przez niego prawa (zasada lojalności, z której m.in. wywodzi się, że państwo nie powinno zastawiać na jednostki pułapek), zasada poprawnej legislacji oraz ochrony godności jednostki, a także proporcjonalności, stanowia wystarczajacy wzorzec ustalania zasad publicznoprawnej ingerencji w prawo własności. Może ona być dokonana jedynie wtedy, gdy uwzględnia się wszystkie te dyrektywy jednocześnie. W wyliczone reguły publicznoprawnej ingerencji w żadnej mierze nie wpisuje się nacjonalizacja.

Wszystko to prowadzi do wniosku, że w przypadku dokonywania wywłaszczenia w drodze ustawy pojawia się uzasadnione podejrzenie, że rozróżnienie obu tych form publicznoprawnej ingerencji w prawo własności nie jest wcale oczywiste. Tymczasem w stosunku do nacjonalizacji nie da się zastosować przesłanki niezbędności, gdyż tylko organy administracji publicznej w drodze postępowania administracyjnego mają możliwość wyważania wielu interesów publicznych i prywatnych i właściwego skorzystania ze środka ultima ratio ${ }^{62}$. W świetle poczynionych zastrzeżeń wywłaszczenie ex lege (np. to, o którym

59 Szewczyk (2003): 654.

60 Pilich (2017): 991.

61 Zob. raport NIK z 25 marca 2014 r., Regulowanie stanu prawnego nieruchomości zajętych pod drogi publiczne, KAP-4101-02-00/2013, nr ewid. 7/2014/P/13/015/KAP, https://www.nik.gov. pl/plik/id,6627,vp,8421.pdf [dostęp: 12.06.2018].

62 Zob. orzeczenie Czeskiego Sądu Konstytucyjnego z 28 czerwca 2005 r., PL US 24/04, nr 327, 2005 Sb (N 130/37 SbNU 641). 
mowa w art. 73 u.w.r.1998) jest bardzo bliskie nacjonalizacji. Okazuje się, po pierwsze, że jest ukierunkowane raczej na przeszłość - służy uporządkowaniu zastanych stanów prawnych, a nie realizacji nowych celów publicznych (np. budowy dróg publicznych czy kolejowych). Po wtóre, dokonywane jest w formie właściwej nacjonalizacji. Nadto odszkodowanie nie jest ustalane z urzędu jak w klasycznym wzorcu (również w specustawach), ale w trybie wnioskowym. Tym samym, co wprost wynika z poprzedniego wyróżnienia, uprawnienie do wystapienia z takim wnioskiem może się przedawnić. Jeśli zatem ustawodawca niejako godzi się, że rekompensata nie będzie ostatecznie wypłacona, to takiej publicznoprawnej ingerencji bliżej jest do nacjonalizacji. Należy jednak zastrzec, że przy nacjonalizacji można pominąć obowiązek rekompensaty, co przy wywłaszczeniu jest jednak niedopuszczalne, nadto ma to być nie jakiekolwiek odszkodowanie, ale - zgodnie z art. 21 ust. 2 Konstytucji RP - słuszne odszkodowanie.

Egzemplifikację zasadnego skorzystania z wywłaszczenia ex lege w obecnych realiach ustrojowych może stanowić jedynie art. 223 ust. 1 u.p.w. W pozostałych przypadkach traktowanie wywłaszczenia jako środka ostatecznego będzie oznaczało dopuszczalność jego przeprowadzenia jedynie na podstawie ustawy, przede wszystkim w drodze aktu administracyjnego, a nie przez ustawę.

\section{WNIOSKI}

Osajda, ogólnie charakteryzując nacjonalizację, doszedł do wniosku, że jest „skonkretyzowanym wywłaszczeniem”63. Prima facie pogląd ten wydaje się zasadny, jednakże przyrównanie go do współczesnych standardów ekspropriacji nakazuje zachować ostrożność. Mianowicie z art. 21 ust. 2 Konstytucji RP wynika, że wywłaszczenie jest środkiem ultima ratio, a rekompensata, ustalana w zamian za szczególną ofiarę, jaką jednostka poniosła na rzecz ogółu, powinna być adekwatna i ekwiwalentna (słuszne odszkodowanie). Także nacjonalizacja może być przeprowadzona za pełnym odszkodowaniem, choć dopuszczalne jest, by było ono częściowe, czy też wręcz pozorne. Jednakże ta ostatnia stanowi często realizację celów politycznych i przejście mienia następuje z pominięciem przesłanki niezbędności, która wyraża się w tym, że celów tych nie da się osiagnąć w inny sposób. Stąd jeśli wywłaszczenie ex lege spełnia standardy konstytucyjne, to jest instytucją różna od nacjonalizacji i tym samym jest dopuszczalne, choć z racji znaczącego obniżenia poziomu ochrony praw jednostki, w tym naruszenia zasady równości wobec prawa (w porównaniu z tymi wywłaszczonymi w drodze aktu administracyjnego), powinno korzystać się z niej wyjątkowo, w szczególnie uzasadnionych przypadkach. Przytoczone przykłady w ustawach epizodycznych z art. 73 u.w.r.1998 na czele, niestety, tych standardów nie spełniają. Stąd w ich przypadku następuje niebezpieczne zbliżanie się takiej publicznoprawnej ingerencji w prawo własności do na-

${ }^{63}$ Osajda (2009): 14. 
cjonalizacji, tym bardziej że ich celem było uregulowanie (uporządkowanie) zastanych stosunków prawnych, a nie realizacja nowych celów publicznych a ta cecha wyróżnia właśnie nacjonalizację. Powyższe implikuje, że jeśli zastosować by kryterium formy przejęcia prawa własności, to art. 73 u.w.r.1998 bez wątpienia traktować należy jako przykład nacjonalizacji dokonanej w demokratycznym państwie prawnym, które to stanowisko zostało wyrażone w piśmiennictwie i nie należy do odosobnionych ${ }^{64}$. Przyzwolenie przez Trybunał Konstytucyjny na dokonywanie takich przekształceń własnościowych spowodowało, że ustawodawca skorzystał z tego środka ponownie i niewykluczone jest, że sięgnie do niego w przyszłości, jako skutek pragmatycznego podejścia do prawa.

Z punktu widzenia nadużyć, jakich dokonał ustawodawca we wskazanych ustawach epizodycznych, być może należałoby postulować de lege ferenda, by na wzór Konstytucji Słowacji i czeskiej Karty podstawowych praw i wolności przesądzić, że wywłaszczenie może być dokonane wyłącznie na podstawie ustawy, co nie musi oznaczać ograniczania się wyłącznie do aktu administracyjneg ${ }^{65}$. Tym bardziej że w orzecznictwie polskiego TK regularnie pojawiaja się stanowiska, że stosowanie wywłaszczenia ex lege może doprowadzić do zacierania się różnic pomiędzy wywłaszczeniem a niedozwoloną przez Konstytucję RP nacjonalizacją ${ }^{66}$. Jako stały element porządku prawnego standardy wywłaszczenia ex lege spełnia natomiast art. 223 ust. 1 u.p.w.

Przy wywłaszczeniu z mocy ustawy, z racji zastosowanej przymusowej formy pozyskania prywatnej własności na cele publiczne, kryterium odróżniającym je od niedozwolonej de facto nacjonalizacji jest nieuchronność obowiązku odszkodowawczego, który powinien uczynić zadość wymogom (standardom) wynikajacym $\mathrm{z}$ Konstytucji RP, przede wszystkim z art. 21 ust. 2, art. 2 czy art. 32. Stąd postępowanie w sprawie stwierdzenia, jakie grunty przeszły na własność podmiotu publicznego, powinno być wszczynane z urzędu, z momentem wejścia $\mathrm{w}$ życie ustawy. Tym samym za niedopuszczalne należy uznać ustalanie odszkodowania na wniosek, którego niezłożenie w określonym czasie może całkowicie zniweczyć możliwość uzyskania rekompensaty.

Współcześnie na wywłaszczenie można patrzeć jako na społecznie akceptowaną publicznoprawną ingerencję $\mathrm{w}$ prawo własności, choć pogląd ten należy wypowiadać w Polsce z dużą ostrożnością. Tym bardziej nie może być postrzegane przez pryzmat nacjonalizacji, o czym ustawodawca zdaje się zapominać. Standardy wynikające z art. 21 ust. 2 Konstytucji RP są bezwzględnie obowiązujące, a wywłaszczenie ex lege jest wyjątkiem od reguły. Można uznać je za dopuszczalne wyłącznie w wyjątkowych sytuacjach, np. zagrożenia integralności kraju, kataklizmu bądź jeśli byłoby to niezbędne dla odrodzenia się Państwa Polskiego. W żadnej mierze jego uzasadnieniem nie moga być względy prakseologiczne, gdyż w istocie oznaczałaby to „drogę na skróty”. Z całą moca należy pokreślić, że ułatwienie zarządzania państwem to powód niewystarcza-

64 Zob. przyp. 48 i 49.

65 Zob. Pawłowski (2018a).

66 Wyrok TK z 21 czerwca 2005, P 25/02, OTK-A 2005, nr 6, poz. 65. 
jacy do naruszenia podstawowych zasad ustrojowych, a akty nacjonalizacyjne są głęboko obce państwu demokratycznemu.

Mimo tych dyrektyw całkiem niedawno, tj. w 2014 r., ustawodawca przesądził, że spółki, które nie przerejestrowały się z rejestru handlowego do KRS, nie tylko z dniem 1 stycznia 2016 zostały z niego wykreślone i utraciły byt prawny, ale także Skarb Państwa nieodpłatnie przejął mienie pozostałe po takich spółkach ${ }^{67}$. Mimo wielu zarzutów, jakie można stawiać wobec przyjętego rozwiązania, niewątpliwie aktualizuje ono dyskurs o możliwości przeprowadzenia nacjonalizacji w RP po zmianach ustrojowych.

Stawomir Pawłowski

Uniwersytet im. Adama Mickiewicza w Poznaniu

womir@amu.edu.pl

https://orcid.org/0000-0002-2060-6638

Banaszkiewicz, B. (2001). Konstytucyjne prawo do własności, [w:] M. Wyrzykowski (red.), Konstytucyjne podstawy systemu prawa. Warszawa: 27-54.

Baran, B. (2009). Prawo cywilne dla zarządców nieruchomości. Warszawa.

Bieniek, G., Rudnicki, S. (2013). Nieruchomości. Problematyka prawna. Warszawa.

Bors, M. (2014). Wywłaszczenie pośrednie i postępujące a ochrona inwestora w świetle międzynarodowego prawa inwestycyjnego. Studia Iuridica Lublinensia 21: 181-203.

Chmielewski, G. (2010). Instytucja wywłaszczenia w regulacjach prawnych Republiki Słowackiej. Przegląd Prawa Publicznego 2: 52-66.

Cibulka, L. (2006). Własność i koncepcje jej ochrony w Konstytucji Republiki Słowackiej, [w:] K. Skotnicki (red.), Własność - zagadnienia ustrojowoprawne. Porównanie rozwiązań w państwach Europy Środkowo-Wschodniej. Łódź: 145-152.

Dudek, W. (1976). Międzynarodowe aspekty nacjonalizacji. Warszawa.

Garlicki, L. (2016). Komentarz do art. 21 Konstytucji RP, [w:] M. Zubik (red.), Konstytucja Rzeczypospolitej Polskiej. Komentarz. Tom 1. Warszawa: Lex/el.

Grzybowski, S. (1974). System prawa cywilnego. Część ogólna. Tom 1. Wrocław.

Ignatowicz, J., Stefaniuk, K. (2012). Prawo rzeczowe. Warszawa.

Kremis, J. (2008). Glosa do uchwały NSA z dnia 5 listopada 2007 r., I OPS 2/07. Orzecznictwo Sądów Polskich 7-8: 591-594.

Kozłowska, D., Mzyk, E. (1997). Grunty warszawskie w świetle orzecznictwa Trybunału Konstytucyjnego, Sądu Najwyższego i Naczelnego Sądu Administracyjnego. Warszawa-Zielona Góra.

Luszniewicz J., Landau, L. (b.d.). Nacjonalizalizacja, [w:] Encyklopedia PWN. <https://encyklopedia.pwn.pl/haslo/nacjonalizacja;3945093.html> [dostęp: 18.05.2018].

Osajda, K. (2009). Nacjonalizacja i reprywatyzacja. Warszawa.

Pawłowski, S. (2018a). Glosa do wyroku TK z dnia 12 grudnia 2017, SK 39/15. Studia Prawa Publicznego 1: 175-186.

Pawłowski, S. (2018b). Modyfikacje klasycznej koncepcji wywłaszczenia a gwarancje praw jednostki. Poznań.

Pessel, R. (2003). Rekompensowanie skutków naruszeń prawa własności wynikających z aktów nacjonalizacyjnych. Warszawa.

Pilich, M. (2017). Państwo jako uczestnik międzynarodowego obrotu cywilnoprawnego (zagadnienia wybrane), [w:] J. Monika, M. Pazdan, E. Rott-Pietrzyk, M. Szpunar (red.), Rozprawy z prawa prywatnego. Księga jubileuszowa dedykowana Profesorowi Wojciechowi Popiołkowi. Warszawa: 973-997.

${ }^{67}$ Zob. art. 9 ust. 2a i 2 b ustawy z 20 sierpnia 1997 r. - Przepisy wprowadzające ustawę o Krajowym Rejestrze Sądowym, Dz. U. 1997, Nr 121, poz. 770 ze zm. 
Powałowski, A. (2009). Przekształcenia własnościowe w gospodarce jako przejaw interwencjonizmu państwowego. Gdańskie Studia Prawnicze 22(3): 27-38.

Powałowski, A. (2011). Przekształcenia własnościowe w gospodarce, [w:] A. Powałowski (red.), Prawo gospodarcze publiczne. Warszawa: 584-588.

Pradelle, A. de La (1959). The International Law Association. Report of the 48 Conference at New York September 1958 (1st to September 7th). Annex III. Printed in Great Britain.

Rudnicki, R. (2007). Własność nieruchomości. Warszawa.

Skwarło, R. (2006). Glosa do uchwały SN z dnia 13 października 2004 r., III CZP 52/04. Samorząd Terytorialny 16(11): 74-77.

Stefańska, E. (2009). Decyzje o odmowie przyznania własności czasowej nieruchomości w trybie dekretu warszawskiego jako przykład patologii w funkcjonowaniu administracji, [w:] D.R. Kijowski, P.J. Suwaj (red.), Patologie w administracji publicznej. Warszawa: 355-372.

Szewczyk, M. (2003). Ingerencja publicznoprawna w prawo własności jednostki w demokratycznym państwie prawa, [w:] J. Filipek (red.), Jednostka w demokratycznym państwie prawa. Bielsko-Biała: 653-661.

Szymczak, M. (red.) (1988). Słownik języka polskiego. Tom 2. Warszawa.

Trzaskowski, R. (2003). Nieodwracalne skutki prawne wadliwej decyzji nacjonalizacyjnej. Przedstawienie dorobku orzecznictwa i doktryny. Kwartalnik Prawa Publicznego 3(3): 9-56.

Zimmermann, M. (1939). Polskie prawo wywłaszczeniowe. Lwów.

Żółtowski, M.J. (2013). Ochrona i restytucja mienia prywatnego w świetle norm prawa międzynarodowego, autoreferat dysertacji doktorskiej (maszynopis), Warszawa.

\section{EXPROPRIATION BY OPERATION OF LAW (EX LEGE) VERSUS NATIONALIZATION - REFLECTIONS ON THE INTERFERENCE OF PUBLIC LAW IN PROPERTY RIGHTS}

Summary

The deliberations presented in this article are an attempt to evaluate the legislative acts issued in Poland after the political transformation, the main purpose of which was to organize the existing factual state of affairs (ownership relations). Particularly groundbreaking in this respect is Article 73 of the Act of 13 October 1998 - Provisions Introducing Acts Reforming Public Administration. The Constitutional Tribunal referred to the interference of public law in the right of ownership as ex lege expropriation, occurring directly by virtue of law. Meanwhile, the removal of ownership in this mode is, as a rule, pertinent to nationalization, which in the present political system is de lege fundamentali unacceptable. Thus, the immediate goal of this study is first of all to distinguish between these two institutions of ownership transformation and then to critically analyze the adopted solutions. The final conclusions indicate that if expropriation ex lege meets constitutional standards, it is an institution different from nationalization and therefore acceptable. However, Article 73 and other similar articles do not meet these standards due to the detailed rules of their making. Doubts arise, for example, when it comes to paying compensation only on request, or to the possibility of its expiration due to the lapse of time.

Keywords: nationalization; expropriation ex lege; the classic concept of expropriation 